\title{
Molnet på jorden
}

\section{Johan Fredrikzon}

\author{
Tung-Hui Hu \\ A Prehistory of the Cloud \\ MIT Press, 2015
}

Det berömda "molnet" är sedan åtminstone ett halvt decennium synonymt med hur vi lagrar och hämtar digitala data. Med sin nebulösa struktur och ständiga men omärkliga närvaro är datamolnet en närmast övertydlig symbol för digital kommunikation som någonting immateriellt, abstrakt och metafysiskt. Tung-Hui Hus bok A Prehistory of the Cloud är den senaste i raden av mediehistoriska undersökningar som försöker att nyansera och korrigera den dominerande uppfattningen av molnet genom att förankra dess nutida utformning i konkreta historiska situationer samt visa på konsekvenserna av det som författaren benämner kulturella fantasier omkring våra fluffiga informationsströmmar. Tack vare bokens flyhänta framställning av originellt empiriskt material ( $\mathrm{Hu}$ är även verksam som poet) knyter den an till så olika publikationer som Bruce Schneiers populärt hållna Data and Goliath (2015) å ena sidan och John Durham Peters lärda medieexkursioner i The Marvelous Clouds (2015) å andra sidan.

$\mathrm{Hu}$ är föredömligt pedagogisk när han leder läsaren i in un- 
dersökningen. Så här sammanfattar han bokens underliggande fråga $\mathrm{i}$ inledningskapitlet: Om molnet är en kulturell fantasi (kapitel 1) av deltagande (kapitel 2) och säkerhet (kapitel 3), vad händer då när användare deltar i sin egen säkerhet? (kapitel 4)? För att besvara frågan går han i tur och ordning igenom molnets nätverk, virtualisering, lagring och gränssnitt. Den som är datatekniskt skolad känner igen upplägget: framgångsättet tillsvarvar OSI-modellen för att beskriva abstraktionslager inom datorarkitektur och -kommunikation. Hu har två huvudsakliga ärenden med sin studie. Dels vill han visa hur de trådlösa nätverk som omger oss vilar på infrastruktur betydligt äldre än datateknik, dels att molnet som begrepp går långt utöver specifika teknologier för att bli verksamt som metafor för vår tids förståelse av informationsteknologi. Så visar författaren hur de tillsynes virtuella tjänsterna alltid kan knytas till fysiska kablar och konkreta datacenter som förbrukar enorma mängder energi och vars ägare köper billig arbetskraft i låglöneländer, samt att dessa rutter inte sällan löper längs gamla järnvägar och avloppstunnlar eller är lokaliserade i forna militärkomplex och bunkrar från kalla kriget. Kunskapen är inte ny, invänder någon, men nog kan den behöva upprepas och då gärna av en inspirerad följeslagare som Tung-Hui Hu. Det intressanta med A Prehistory of the Cloud är kombinationen av ett brett kulturhistoriskt anslag med rika associationer till de senaste decenniernas politiska utveckling och en gedigen förståelse för datorsystemens teknologiska ramverk. $\mathrm{Hu}$, litteraturvetare och poet med en bakgrund som nätverkstekniker, tar med läsaren in mellan de surrande fläktarna i de enorma serverhallarna för att så att säga tvinga materialiteten ur molnet. Greppet påminner snarast om när Sven Lindqvist i Hemmaresan (1959) följde rören på dass hela vägen till reningsverket och krävde att få veta varifrån vattnet kom och hur systemet såg ut bakom kaklet, under vägen, på andra sidan skogen. Hu liknar dataflödet vid just vattnet i kranen, denna samtidigt komplexa och banala tjänst som blir osynlig $\mathrm{i}$ samma stund vi lär oss att ta den för given. Det går att se Hus arbete som del av en mediearkeologisk utgrävning av de trådar - synliga och ej - som löper kors och tvärs över världen, en vilja 
att veta riktad mot infrastrukturen och dess svarta lådor, en digital "gräv-där-du-står"-rörelse med kritiska och demokratiska undertoner som vi förmodligen bara sett början på.

Det övergripande syftet med framställningen är att kritisera de slentrianmässiga attityderna till de globala datanätverken molnen - som oproblematiska gratisverktyg för effektiv kommunikation, ett slags outtömliga reserver för beräkningskraft och lagringsutrymme, lätta som luft och med demokratisk och frigörande potential. Här riktas kritik mot såväl etablerad medieforskning som politiska diskurser, branschmyter och populärvetenskapliga förenklingar. I argumentationen för sin sak aktiverar författaren ett mångskiftande källmaterial. Med några kvicka nedslag kan han visa hur nästan all internettrafik i USA löper längs rutter som etablerades på 1800-talet, att de i själva verket är starkt centraliserade och styrs av sex privata telekombolag. Att vi ändå talar om nätets distribuerade, fria och öppna karaktär menar $\mathrm{Hu}$ pekar mot att nätverket i första hand är en idé, en seglivad uppfattning om att "allt är sammankopplat", en utbredd åkomma som han med stadsarkitekten Doxiadis från 1970-talets Detroit betecknar "nätverksfeber": begäret att koppla ihop alla nätverk, varje liten informationsdel med alla andra. Ett slags motsvarighet, tänker man sig, till insamlingsiver, dokumentationshysteri, bevarandepanik och liknande institutionspatologier som tyngt arkiven och vetenskaperna sedan länge.

Bakom drivkraften att koppla ihop allt, skriver $\mathrm{Hu}$, finns en känsla av hot, en tärande osäkerhet om en obevakad läcka, en föraning om en nod som ännu inte är hopflätad med resten; en mörk fläck på kartan. Här uppstår, enligt författaren, det paranoida subjekt som ständigt eftersträvar att förmå omvärlden att ta form i enlighet med en inre kognitiv ritning med vars hjälp allting ska bli synligt. Problemet med paranoia som drivkraft är inte bara att den bygger på mer eller mindre ogrundade fantasier om fara. Genom att agera utifrån den upplevda hotbilden, bekräftar den indirekt dess existens vilket i förlängningen motiverar andra åtgärder, till exempel att ytterligare förskansa sig - eller åtminstone sina data - i skyddsrum eller öka graden 
av övervakning. Det tillgängliga och öppna datamolnet modellerat på förföljelsemani, således. Gamla frågeställningar kring datasäkerhetens psykologi tangeras med förtöjningar bakåt till krigets strategi och underrättelseverksamhetens historia.

Om besattheten att koppla ihop världens alla data i en komplett helhet bär paranoida drag, menar $\mathrm{Hu}$ att datacentrets arkitektur hellre är melankolisk till sin natur. Till varje pris vill det skydda och bevara uppgifter från yttre krafter. Liksom skyddsrummen från mitten av förra seklet, avsedda att stå emot bombräder och kärnvapen, förkroppsligar datacentret ett ständigt avvaktande inför katastrofen. Denna ordning - luftburna nätverk som är inlåsta i berget - gör att molnet på samma gång härbärgerar motsatta temporaliteter: realtid och väntan. Datahallen djupt inne i berget blir både vakttorn och likkista. Författaren gör flera träffande observationer när han rör sig $\mathrm{i}$ bunkermentaliteternas topografier, från Iron Mountain utanför New York till Pionen på Söder i Stockholm, där 1900-talets betongdörrar stänger inne 2000-talets digitala routrar. Genom det detaljerade historiska exemplet, genom att följa infrastrukturen i tid och rum, lyckas Hu visa att ingenting är fullt så nytt, fritt eller säkert som vi gärna vill tro. Framförallt lyckas han demonstrera hur nätaktivister och regeringar ofta drivs av samma upplevelse av hot, av idén att nätet är ofritt eller riskerar att bli det: "Internet måste försvaras", skriver han, med en bli blinkning till Michel Foucaults föreläsningar vid mitten av 1970-talet om krigets och rasismens problem. Lagringstjänster i molnet, "cloud storage", blir då ett sätt att skydda sina data från den Andre. Det som ur en vinkel ser ut som en global rörelse för nedrivna gränser och fritt tankeutbyte kan ur en annan beskrivas som fortsättningen på 1800-talets imperialism. Här gör $\mathrm{Hu}$ en viktig insats genom att problematisera säkerhetstänkandets förmåga att normaliseras till den grad att vi inte längre ser hur dess mekanismer från början är uppbyggda kring uteslutandets och utestängandets principer.

Till och med de läsare som redan är bekanta med den sortens analyser, bjuds på en rad intressanta fallstudier, till exempel om hur kollektivet Ant Farm i början av 1970-talet körde runt i en 
ombyggd skåpbil med vars hjälp folk gavs tillgång till datorer och videotjänster vid vägkanten i ett "truckstop network" för "media nomads" på utvalda platser i USA. Här skapades en vision av mobil data med hjälp av bilen och televisionen, en vision som skulle tas vidare när Stanford Research Institute 1976 för första gången upprättade kommunikation mellan två olika typer av datornätverk - "molnen" ARPA NET och PR NET - och där den ena noden utgjordes av just en skåpbil som parkerats utanför Rossotti's biker bar i Palo Alto för att pröva utrustningen i en "ogästvänlig miljö" så att militären kunde övertygas om dess lämplighet. Den sortens oväntade utflykter i nätets historia tillhör den verkliga behållningen med boken. Molnet är här varken det demokratiska universalverktyg eller det krigsfödda övervakningsinstrument det ofta framställs som - det är både och, samtidigt, och mer ändå.

En av de mest givande delarna av boken är kapitlet om "timesharing", alltså resursdelning vid datoranvändning på 1960- och 1970-talen. Det vill säga tiden innan datorn blev "personlig", en tid då varje beräkning var dyrbar och forskare, statistiker och andra fick stå i kö för att få tillgång till datorns förmågor. Timesharing var en metod för att lösa problemen med väntetid genom att låta datorn blixtsnabbt växla mellan olika förfrågningar så att var och en upplevde det som att hela dess beräkningskraft stod till ens exklusiva förfogande, trots att varje sekund av processorns arbete i själva verket fördelades på flera uppgifter. Ur time-sharing-modellen härleds även praktiker som att skilja på och namnge användare, att hålla koll på vad var och en sysslar med, hur resurser förbrukas m.m. Hu visar hur timesharing inte bara innebar "användarens" [the user] födelse utan även speglade en ekonomisk omställning i samhället från strikt lönearbete till olika former av flexibelt arbete utifrån personliga preferenser. Den här utvecklingen drar författaren hela vägen till nutida motsvarigheter som att oavlönat recensera produkter och rekommendera tjänster i onlineforum. Kritiken mot vårt omfattande gratisarbete får här en alternativ bakgrund som man inte behöver köpa fullt ut för att finna tänkvärd.

Författaren ser här början på värderingen av realtid som en 
ekonomisk storhet men även de första sammanblandningarna av begreppet "free" $i$ betydelsen gratis respektive fri, samt alla politiska och kapitalistiska implikationer det kan få när vi blandar ihop personlig och ekonomisk intimitet. Diskussionen är värdefull eftersom den öppnar för en kritik som hittills varit anmärkningsvärt svag gentemot nätets ekonomiska strukturer, nämligen konsekvenserna av ytligt sett kostnadsfria tjänster och varor som i slutändan konsumerar, så att säga, användarens eller medlemmens kanske viktigaste resurs - hennes tid - och därmed ytterst hennes frihet att tänka och handla självständigt. Nog kan det gå lite väl fort ibland när $\mathrm{Hu}$ associerar mellan olika perspektiv och fenomen - till exempel blir vissa psykoanalytiska läsningar av molnets egenskaper något långsökta - men oftast görs det med en smittande energi och retorisk elegans som måste bejakas. Emellertid ger undersökningens upplägg och anspråk anledning att fundera över hur vi skriver mediehistoria. De centrala värdena av A Prehistory of the Cloud är tveklöst författarens förmåga att öppna upp en ganska trång och ytligt kanoniserad berättelse om nätets födelse och hur de tidiga visionerna lett fram till vårt digitala samhälle med alla dess fördelar. Men samtidigt är $\mathrm{Hu}$ aldrig sen att själv slå fast hur nutidens "moln" har direkt samhörighet med stordatorernas kontofördelning för ett halvt sekel sedan eller hur det går en rak linje från kalla krigets bunkrar fram till dagens satellitstyrda drönarattacker. Han verkar således $\mathrm{i}$ en tradition där värdet av historieskrivningen till stor del grundar sig på huruvida fynden tydligt kan länkas till aktuella fenomen. Det gör framställningen potent men bitvis en smula vidlyftig, någon gång ansträngd.

Det som överlag fungerar sämst är författarens försök att föra in "suveränen" igen i den maktkritiska diskursen som först Foucault (delvis) övergav till förmån för en disciplinär stat, och som sedan Gilles Delezue och andra försökte ersätta med idén om kontrollsamhället. Till Hus försvar kan sägas att han (liksom Foucault) inte är beredd att förklara någon form av maktutövning obsolet, men det han kallar för "the sovereignty of data" förblir till slut något oklart. Till undersökningens största förtjänster hör istället att den först ställer upp ett antal narrativ 
som justerar utbredda troper och ytliga iterationer av myter för att sedan presentera små motbilder till sin egen historieskrivning. Detta genererar en läsart som inte tillåts vila mot enkla förklaringsmodeller. $\mathrm{Hu}$ funderar även kring det faktum att bankkonton, pornografi, militära dokument och e-post hålls noga åtskilt mellan användare men ändå ligger intill vartannat rent fysiskt i samma server någonstans i molnet. Kanske finns det rum för möten mellan individer när infrastrukturen rasar samman, ungefär som under en brandövning i en skyskrapa då människor som aldrig tidigare sett varandra trots att de arbetar i samma byggnad kommer i samspråk.

Författaren lyckas även fördjupa diskussionen om digitala motståndsrörelser genom att visa hur de i sista hand uppträder enligt de strukturer som en nyliberal ideologi förutsätter: de är aktiva deltagare, engagerade användare inom systemet, de delar data med hjälp av samma verktyg som marknaden eller staten. När vi taggar varandras bilder på Facebook för att bygga relationer kring en politisk demonstration utför vi ett slags obetalt arbete som i längden syftar till att bygga upp världens största databas för ansiktsidentifiering. Även mer avantgardistiska, subversiva och maktkritiska initiativ verkar inom en övergripande ideologi inte minst som de tvingas anpassa sig till standarder och protokoll av olika slag. "A hacktivist project", skriver $\mathrm{Hu}$, "to undermine the government looks like a security project meant to bolster the government". Denna gräsrotsbevakning eller "sousveillance" är problematisk även därför att den reproducerar en tvivlets blick som gränsar till det paranoida och riskerar därmed att motverka sitt syfte i längden. Resonemanget påminner om Bruno Latours självkritiska betraktelse om en intellektuell tradition som ifrågasätter till den grad att den riskerar att spela i händerna på konspirationsteoretiker.

Med stöd av bland andra Paul Virilio och Giorgio Agamben associerar författaren friskt kring hur kriget numera varken är ett undantag eller något som enbart stater eller terrororganisationer ägnar sig åt. Tvärtom visar $\mathrm{Hu}$ hur vanliga medborgare - användare - aktivt deltar i jakten på hotfulla eller främmande element tack vare molnets förmåga att samla avancerade verk- 
tyg för att söka i stora dataset, jämföra mönster, spåra via kartor och så vidare. En radiohackare i Holland som snappar upp och bloggar om det amerikanska stridsflygets positioner riskerar att underlätta för motståndarsidan under NATO-attackerna mot Libyen 2011. Med en hobbyutrustning för 500 dollar kan han påverka säkerheten för ett flygplan värt en halv miljard. En 48årig mellanchef på glassbaren Dairy Queen i Tuscon, Arizona bläddrar på sin fritid igenom satellitfotografier för att via Twitter tipsa NATO om Khaddafis kommunikationshögkvarter. Några timmar senare meddelar han stolt att försvarsalliansen bombat exakt de platser han pekat ut. Här är det återigen det närgångna empiriska materialet som får studien att lyfta. Att det verkar finnas ett slags långsamt våld (Rob Nixons begrepp) som utövas inom datamolnens domäner - inte sällan i klassisk nyliberal eller imperialistisk stil - är man nog beredd att hålla med om efter att ha tagit del av A Prehistory of the Cloud. Men om författaren sätter fingret på många paradoxer och inkonsekvenser eller rena felslut beträffande den digitala världens möjligheter till effektiv kritik och motstånd, förblir han ganska luddig beträffande vilka andra vägar som borde prövas. 